\title{
Article \\ Potting Christianity: Ecumenical Worship in Its Multicultural and Multi-Ethnic Context
}

\author{
Swee Hong Lim
}

check for

updates

Citation: Lim, Swee Hong. 2022. Potting Christianity: Ecumenical Worship in Its Multicultural and Multi-Ethnic Context. Religions 13: 73. https://doi.org/10.3390/ rel13010073

Academic Editor: Eunjoo Mary Kim

Received: 25 November 2021

Accepted: 10 January 2022

Published: 13 January 2022

Publisher's Note: MDPI stays neutral with regard to jurisdictional claims in published maps and institutional affiliations.

Copyright: (C) 2022 by the author. Licensee MDPI, Basel, Switzerland. This article is an open access article distributed under the terms and conditions of the Creative Commons Attribution (CC BY) license (https:// creativecommons.org/licenses/by/ $4.0 /)$.
Emmanuel College, Victoria University, The University of Toronto, Toronto, ON M5S 1K7, Canada; sweehong.lim@utoronto.ca

\begin{abstract}
In the gardening world, potting refers to the cultivation of plants by cutting, layering, and replacing nutrients-depleted soil with new soil in larger pots to accommodate the growth process. This understanding seems helpful in describing ecumenical worship. There are two perspectives about this phenomenon. On one end of the liturgical practice spectrum, it is perceived as a "leastcommon-denominator" worship form where contested expressions are cast aside and replaced by elements that are acceptable by everyone. As a result, ecumenical worship is held up as a product of complex negotiation but displays a remarkable lack of spiritual depth in its outcome. On the other end, there is the World Council of Churches-a fellowship of 350 churches that is regarded as the epitome of ecumenism in practice particularly its worship celebration. The assembly, convened every eight years, is seen as a "best practice" showcase for ecumenical worship. In fact, many of the "global songs" being sung by our congregation were premiered in this ecumenical setting. How might we make sense of these perceptions? To that end, this article seeks to describe a suitably appropriate method in planning ecumenical worship and to identify elements that this worship genre needs to consider in its rendition. The efforts of the 2022 assembly worship planning committee of the World Council of Churches serves as the case study. Theo-liturgical principles that define this worship design are examined and discussed. By this, insights may be garnered to help local congregations appreciate this distinctive liturgical form that has its raison d'etre as an expression of Christian reconciliation and unity and to understand what is needed to successfully design such services. In so doing, the work of congregations may be strengthened to face the resurgence of racism and xenophobia in their local contexts.
\end{abstract}

Keywords: ecumenical worship; interconfessional prayer; world council of churches; assembly; spiritual ecumenism; receptive ecumenism; best practice principle

Ecumenism is not about conformity on the lowest possible level. It should rather have to do with sharing spiritual and liturgical treasures.

Liborius Olaf Lumma (Lumma 2018)

\section{Introduction}

In the gardening world, potting refers to the cultivation of plants through the introduction of new soil in larger pots to accommodate the growth process. In my view, this understanding seems helpful in describing the desired outcome for ecumenical worship-that of engaging the churches' worship practices to express ecclesiastical unity. Yet, not surprisingly, given inherent theological differences, there are competing opinions about such efforts. For this reason, this article seeks to present a suitably appropriate method in the design process and to identify elements that this worship genre needs to consider in its rendition. Drawing on the efforts of the 2022 assembly worship planning committee of the World Council of Churches, theo-liturgical principles that define this worship design are examined and discussed. In particular, there are the closely linked theological premise of both Spiritual Ecumenism formulated by Abbé Paul Couturier of Lyons in the 1930s 
and the concept of Receptive Ecumenism postulated by British Catholic theologian Paul D. Murray in 2007 (Pizzey 2019, p. 62).

On one end of the liturgical practice spectrum, ecumenical worship is perceived as a "least-common-denominator" worship form where contested expressions are cast aside and replaced by elements that are acceptable by everyone. As a result, ecumenical worship is held up as a product of complex negotiation but displays a remarkable lack of spiritual depth in its outcome. In his article, Ecumenical Services-a Little Known Type, GermanAustrian liturgical scholar Lumma offered this description of the practice of constituting ecumenical worship ordo. He surmised,

Ministers from different denominations meet at a negotiating table. They come to mutual agreements on Scripture readings, hymns, intercessory prayer, the Lord's prayer, maybe they write new prayers. A preacher is chosen, and eventually, all the necessary offices in the liturgy are shared among the ministers. Done! The result is a newly created service consisting of elements that everyone can agree too. It is a "least-common denominator-" service. (Lumma 2018)

In this planning process, Lumma noted the extensive preparation for the complex undertaking results in a worship event that is seemingly lacking in spiritual depth. He proposes that perhaps ecumenical liturgical effort can be better served by taking seriously the call to "share more deeply in traditions which often have developed from common roots" (Article 117) from the Ecumenical Directory: Directory for the Application of Principles and Norms on Eumenism (Roman Catholic Church, Pontifical Council for Promoting Christian Unity 1993). Not surprisingly, this call for "a better practice" has been heeded by the organization known to be the epitome of ecumenism, the World Council of Churches (henceforth abbreviated as WCC).

This fellowship of three hundred and fifty confessional churches (or denominations) convenes every eight years to conduct its business. For this purpose, it draws on spiritual life expressions of prayers, song, and illustrative actions to aid in its deliberations. With this intention, the prayer life designed for the assembly has the important task of sharing "spiritual and liturgical treasures." In fact, an obvious first fruit of this sharing is the proliferation of newly composed "songs from the majority world or global south." In fact, many of these non-western songs that are now widely sung by our local churches were introduced in WCC assemblies.

Nevertheless, the comment of Lumma is insightful. Ecumenical worship is fraught with inherent tension. Roman Catholic liturgical scholar Teresa Berger, in investigating the practice of worship in the ecumenical movement through the reports of the Faith and Order conference of the WCC, noted that,

In Lund (World Council of Churches, Faith and Order Commission 1952 conference report) ecumenical reflections on worship concentrated on the fact that in worship "disunity becomes explicit and the sense of separation most acute." The conference maintained: "In worship we meet the problem, nay, rather the sin of the disunion of the church in its sharpest form". (Berger 2003)

She observed that,

Lund 1952 was a first attempt to formulate both the existing agreement and the unsolved problems regarding the meaning and practice of worship. The formulation of agreement appropriately and convincingly begins with the Trinitarian basis (see Trinity) and pneumatological context (see Holy Spirit) of worship. "We worship one God, Father, Son and Holy Spirit, the Triune God, by whose Spirit all true worship is inspired and unto whom all Christian worship is offered." The agreed statements which follow concern questions that are anthropological (worship involves the whole person), liturgical (a drawing together of the common elements observed in Ways of Worship), sacramental (the appreciation of both word and sacrament) and ecclesiological (worship always takes place within the communion of saints). Also mentioned is a theme that would be 
stressed repeatedly in subsequent ecumenical documents on worship: "However we view the church's worship, we are unanimous that its setting is the church's mission to the world." The section on unsolved problems takes up more specific questions (e.g., the precise relationship between word and sacrament and the place in worship of saints and the departed). (Berger 2003)

Ultimately, Berger concluded that,

Lund's recommendations to the churches emphasize unity as the aim of all the studies on different patterns of worship. Some recommendations re-appear in later documents, indicating that in the meantime the member churches have not taken them seriously enough. (Berger 2003)

Eden Grace, a youth delegate from the Religious Society of Friends (Quakers) to the 9th General Assembly of the World Council of Churches in Harare, Zimbabwe, in 1998 observed that,

Both the experience of worship in the World Council of Churches, and the WCC's discussions about worship, have developed, deepened, and changed emphases over the course of [time]. (Grace 2002, p. 3)

From the 1998 Assembly, she offered her perspective about ecumenical liturgical practice,

The common worship at ecumenical events typically took the form of a rotation of confessional liturgies, "shared" with conference participants for the purpose of mutual edification. Yet even from the beginning there were attempts to express a shared worship of the ecumenical gathering itself, united even in its cultural and theological diversities. (Grace 2002, p. 3)

Clearly from these voices, ecumenical worship is complex in design yet yields uncertain results. Indeed, with multiple forces involved in constructing a meaningful ordo to speaking meaningfully to and for its diverse constituency, might there be some best practice principles we can appreciate from the design process? More importantly, might the approaches of Spiritual and Receptive Ecumenism be efficacious in this context? In my opinion, the regular gathering of the WCC serves as an appropriate setting for this opportunity of learning. Previous essays examining ecumenical worship tended to comment on the "finished product" of the worship phenomenon as experienced by the authors. While helpful, this perspective offers limited insight as to how the prayers were designed, how the planning team navigated through theological differences in the design process, and so forth. However, through my involvement as a member in the assembly worship planning team for the 11th Assembly of the WCC at Karlsruhe, Germany in 2022, I assert that my observation as an embedded participant-observer can offer insight into the design process. In so doing, I hope this account can help local congregations better appreciate this distinctive liturgical form that has its raison d'etre as an expression of Christian reconciliation and unity.

\section{In the Beginning}

Assembly worship planning at the WCC is a collaborative effort that begins in earnest approximately three years before the event. The WCC Central Committee that was elected at the last assembly in 2013 creates and populates the Assembly Planning Committee (henceforth abbreviated as APC). At the same time, suitable persons from various denominations are identified and invited to serve on the Assembly Worship Planning Team (henceforth abbreviated as AWPC) for a term of three years (World Council of Churches 2019). The AWPC serves within the APC. With their appointments, AWPC members are committed to attend both "In-Person" and video-conference meetings to plan and design the prayer services. However, it is important to understand that the worship design work of this committee is not carried out independently but informed by the assembly theme adopted by WCC leadership (Hammes 2021). As Verena Hammes, general secretary of the Council of Christian Churches in Germany, reminded us, 
Assembly themes are not simply random slogans, chosen by chance and therefore without significance. They serve as a guideline for the assemblies, as a word spoken to delegates and to the wider world as an orientation for debate, decision, and, not least, prayer. (Hammes 2021, p. 405)

Therefore, the theme is the backbone and essence of the assembly. It serves as the primary focus that theologically informs and shapes all activities at the assembly. The WCC publication, Let the Spirit Speak to the Churches, asserts that "in all WCC assemblies, reflections on the theme and its implications for the church's witness have provided an overall theological framework for the work of the assembly" (World Council of Churches 1990, p. xi).

Given that members of the AWPC come from all over the world, the first meeting of the AWPC was occupied with orientation of its members to the "big picture" overview of the forthcoming assembly. At the same time, having committee members from various parts of the global and being from different denominations ensured that worship design deliberations would intrinsically reflect diverse ecclesial perspectives, experiences, and theological ethos. Diversity is fait accompli. This manner of constituting the planning team resonates with the key principles of both the Spiritual and Receptive Ecumenism movements that shape church unity dialogical efforts of the World Council of Churches among its member churches. In essence, these movements ask, "what is it that we in our tradition need to learn and receive, with integrity, from others?" (World Council of Churches 2021, p. 31) These approaches call for the AWPC to be respectful and open to all Christian traditions in the spirit of John 17:21, where the scripture urges, "that they may all be one. As you, Father, are in me and I am in you, may they also be in us, so that the world may believe that you have sent me" (John 17:21, NRSV).

Also at the AWPC gathering, purposeful efforts were made to explain the key tasks of the committee, working groups were formed, timelines projected, meetings with the local host committee scheduled, and a visit to the proposed assembly site was held. Relevant WCC documents like the Final Report of the Special Commission on Orthodox Participation in the WCC were shared and clarified to ensure that there was explicit understanding of terminologies being used by WCC by AWPC members. In the Special Commission report, it defines two key terms used for the assembly, that of "Confessional common prayer" and "Interconfessional common prayer." The report states,

"Confessional common prayer" is the prayer of a confession, a communion, or a denomination within a confession. Its ecclesial identity is clear. It is offered as a gift to the gathered community by a particular delegation of the participants, even as it invites all to enter into the spirit of prayer. It is conducted and presided over in accordance with its own understanding and practice. "Interconfessional common prayer" is usually prepared for specific ecumenical events. It is an opportunity to celebrate together drawing from the resources of a variety of traditions. Such prayer is rooted in the past experience of the ecumenical community as well as in the gifts of the member churches to each other. But it does not claim to be the worship of any given member church, or of any kind of a hybrid church or super-church. Properly understood and applied, this distinction can free the traditions to express themselves either in their own integrity or in combination, all the while being true to the fact that Christians do not yet experience full unity together, and that the ecumenical bodies in which they participate are not themselves churches. (World Council of Churches, Central Committee 2002, Final Report, article 42)

The WCC document elaborates,

15. When we gather to pray together at WCC events, there are occasions when the prayer has been identified with one confession or church within a confessional tradition-hence the term "confessional common prayer." More often, common prayer in ecumenical settings is prepared from a combination of traditions. Such common prayer has often been called "ecumenical worship," but this term can 
be imprecise and misleading, and therefore should not be used. Instead, a more precise term would be "interconfessional common prayer." Distinguishing between confessional and interconfessional common prayer, along the lines drawn below, may provide a greater clarity — both spiritually and ecclesiologically-to the prayer life of WCC events.

- Confessional common prayer is the prayer of a confession, a communion, or a denomination within a confession. It has a particular ecclesial identity. Examples would include the Service of the Word of a Lutheran church, such as the ELCA; or the healing rite of a united church, such as the United Church of Canada; or the Uniting Church in Australia. It could be a Roman Catholic Vespers service or an Orthodox Matins service.

- Interconfessional common prayer is usually prepared for specific ecumenical events. It does not emerge out of a single ecclesial tradition or one church. It may represent patterns that churches have in common (Service of the Word, daily office), but it is not the established liturgy of one confession. It has no ecclesial standing; it is normally designed by an ad hoc committee (World Council of Churches, Central Committee 2002, Final Report, Appendix A, article 15).

It was also made explicit that the term "ecumenical worship" will not be used in the context of WCC. The report provides the rationale for this assertion. It states,

The term "ecumenical worship" has caused confusion about the ecclesial character of such worship, the ecclesiological status of the WCC, and the degree of unity that has in fact been achieved. For these reasons, the phrase "ecumenical worship" will not be used. (World Council of Churches, Central Committee 2002, Final Report, Appendix A, article 2)

To build team cohesion for the task, time was also set aside to strengthen rapport and mutual understanding among committee members. Preliminary discussion of the committee centered on examining the theme and brainstorming on how it may be expressed in the scope of the "Interconfessional common prayer" setting. Given that denominations with local parishes at the assembly site would be invited by WCC to plan the "Confessional common prayer" gatherings, the AWPC focused its attention on the "Interconfessional common prayer" events. These consist of the Opening, and Closing, and the six morning prayers.

\section{Towards Interconfessional Prayer Design}

At its first meeting in 2019, members of the AWPC were scheduled to lead devotions from their ecclesial tradition at each morning and evening. Over six days, different types of prayers were experienced. The remaining time of this first meeting was spent on collecting ideas that speak to the theme. This included possible scriptural narratives, illustrative (symbolic) actions, and prayer components such as songs, prayers, etc. Smaller working groups were organized to ensure that all opinions were heard and documented. Musicians in the AWPC were formed into a group and tasked with developing the approach to call for new songs and to vet and recommend these songs to the AWPC when the prayer services were being designed. At regular intervals, working groups reported their progress. Towards the end of the first AWPC meeting, video-conferencing-based working meetings were scheduled. Particularly time-demanding was the musician working group that was tasked with setting up a schedule to have a process to review new music submissions. The meeting concluded with the recommendation of various scriptural narratives and approaches of the theme to the Assembly Planning Committee for consideration. These were favorably received.

In the midst of the global pandemic, the AWPC held its second meeting through video conferencing. In this meeting, held over multiple video conferencing sessions, the committee began deliberating in earnest the various scriptural narratives and approaches. 
This gave rise to the proposal of an initial ordo for the "Interconfessional common prayer" that reflected the parameters provided by the WCC, which state,

22. Interconfessional common prayer in an ecumenical context is an opportunity to express together those things which we have in common and to rejoice that "what unites us is stronger than what divides us." We can experience the variety of cultural forms with which Christian faith is expressed. However, interconfessional common prayer should take care not to prejudge, implicitly or explicitly, those theological points on which the churches are still divided.

23. Interconfessional common prayer at WCC gatherings would be well served by the use of a structure or ordo, based on the ancient Christian patterns. In developing the ordo, the planning committee might draw, for example, on the daily offices or on the service of the word. Common prayer should strive for a coherence that integrates the various elements into a unified purpose. Committees might consult the work of the worship committee for the 1998 Assembly in Harare in regard to the application of an ordo in interconfessional common prayer. In discerning how to enact an ordo in a particular ecumenical context, committees should make use of elements that have been "ecumenically-tested" by prior use and reception, as well as provide opportunity to receive fresh offerings from the worship life of the churches. The balance between new and familiar elements must be carefully discerned.

27. Use of symbols and symbolic action: Symbols and symbolic actions chosen for prayer in ecumenical settings ought to be readily understood by a culturally and confessionally diverse ecumenical gathering. When using elements that are particular to one tradition, these should be presented in a way that honors the integrity of that tradition and is meaningful in ecumenical usage. Some symbols may not translate well between particular cultures and ecumenical settings, and some may be too contrived to be useful for common prayer. At ecumenical gatherings such as WCC events, we should expect to experience a variety of symbols, some of which are unfamiliar to some participants. Such symbols will require explanation.

30. Leadership of women: When common prayer is being offered in a confessional form, the practice of that confession in regard to leadership of women should normally apply. For interconfessional common prayer, a decentralized leadership and equality of participation allow for any participant-male or female and clergy or lay-to take any role. In an ecumenical context, we come together with a range of positions on the question of ordination of women, both between and sometimes within our churches, and we are not yet ready to reconcile these differences. Thus, planners should refrain from taking a confrontational stance on the question of ordination of women by implying that the current practice of a particular church is the only possible Christian position on the issue.

31. Unfamiliarity: Care should be taken that our common prayer invites participants into particular contexts and symbols rather than asking them to watch it done as a cultural display. For major events (and especially for first-time attenders), this will probably entail an orientation to the experience, explaining what will happen and what it means. The question of how to make common prayer accessible for those who are not familiar with the form is equally relevant for both confessional and interconfessional common prayer. Each individual enters into the experience according to his or her own conscience, yet we should strive to allow participants to move beyond being simply spectators of unfamiliar rites. The elements of common prayer should not themselves become the focus of common prayer but rather should serve to facilitate the genuine prayers of the community. (World Council of Churches, Central Committee 2002, Final Report, Appendix A, articles 22-23, 27, 30-31) 
With these principles in mind, the AWPC proposed to be mindful of the pilgrimage imagery that was found in the "interconfessional common prayers" of previous assemblies. In particular, the 10th assembly at Busan, South Korea in 2013 with its theme of "God of life, lead us to justice and peace" (World Council of Churches 2013). At the same time, members of the AWPC finalized the scriptural narratives that could embody the assembly's theme, "Christ's love moves world to reconciliation, and unity." Following extensive discussion, the identified narratives were crafted into the interconfessional prayers for the assembly. At the same time, close attention was paid to the developing ordo to ensure appropriate transition between various prayer segments and to ensure that the ordo was coherent over the many days of the assembly. In this meeting, logistics for the assembly's "Interconfessional common prayer" were also discussed and recommendations given to the WCC leadership to finalize worship space design. Since the 6th assembly at Vancouver (Canada) in 1983, a tent-like prayer space has served to house the work of common prayers at each subsequent assembly (Pacific Mountain Regional Council Archives, United Church of Canada 1983, 2:18-2:45). Not surprisingly, a similar outdoor design was decided for the 2022 event in Germany as well. This structure will be used for all prayer events.

For its final meeting before the 2022 assembly, the AWPC will work on finalizing the design of the interconfessional prayers and preparing these for publication. AWPC members will also be assigned roles and responsibilities for interconfessional prayers. Some will serve as musicians, song leaders, and prayer leaders and coordinators. The committee will also work on identifying and recruiting additional song leaders to support the music-making work at the assembly. This is because one of the guiding principles of interconfessional common prayer is to have prayers spoken in the official languages of the WCC and songs taught and led in their original languages by leaders from where the songs originated. Once the songs have been finalized, the music working group will work to create musical arrangements for the selected songs. Concurrently, the AWPC will determine rehearsal times for musicians, worship presiders, local choirs, and even assembly delegates and share this information widely to facilitate participation in the prayer life at the assembly. It goes without saying that every aspect of the common prayers will be reviewed and rehearsed at the assembly prior to its rendering because of the multilingual dimension, its strong dependency on multicultural music-making, and use of symbolic (illustrative) actions.

\section{Benefits for Local Context}

How might the principles of designing "Interconfessional common prayer" strengthen the efforts of our local churches seeking to build bridges in their communities? In my opinion, I believe there are three valuable best-practice principles. First is the presence of power dynamics involved in planning ecumenical worship design. Failure to recognize the reality of this would surely doom any well-meaning effort resulting in the scenario of the "least-common-denominator" service rather than one that intentionally shares "spiritual and liturgical treasures." Concerted efforts to maintain open communication and willingness to grapple with liturgical differences are key to overt Christian unity. This is the desired outcome of Spiritual Ecumenism envisioned by its founder, Couturier, as well as Murray who postulated Receptive Ecumenism (Pizzey 2019, p. 65). At times, gracious acceptance of differences and the willingness to explore alternatives might prove helpful. Equally important is to recognize that this service design is distinctive for the occasion and not intended to be "confessional." Consider this thought guidelines from the WCC report,

17. In spite of these realities, preserving the distinction between confessional and interconfessional common prayer at WCC gatherings, and making it explicit (i.e., identifying each event accordingly), can be useful in addressing many of the ambiguities and tensions associated with common prayer. Properly understood and applied, this distinction can free the traditions to express themselves either in their own integrity or in combination, all the while being true to the fact that 
Christians do not yet experience full unity together and that the ecumenical bodies in which they participate are not themselves churches.

- Confessional common prayer expresses the integrity of a given tradition. Its ecclesial identity is clear. It is offered as a gift to the gathered community by a particular delegation of the participants, even as it invites all to enter into the spirit of prayer. It is conducted and presided over in accordance with its own understanding and practice.

- Interconfessional common prayer is an opportunity to celebrate together drawing from the resources of a variety of traditions. Such prayer is rooted in the past experience of the ecumenical community as well as in the gifts of the member churches to each other. However, it does not claim to be the worship of any given member church or of any kind of a hybrid church or super-church. It is not (or ought not be) celebrated or presided over in such a way that would associate it with any one church or imply that it has an ecclesial status (World Council of Churches, Central Committee 2002, Final Report, Appendix A, article 17).

When all parties are aware of this power dynamics, the next matter would be rooting the design in a commonly shared liturgical ordo. In so doing, the ordo transcends confessional boundaries and is not the exclusive showcase for a particular denomination but can bear the gifts and treasures for all denominations. A helpful starting point would be to identify what worship elements are common and what elements are not. A valuable follow-up question would be to ask what elements can be shared. In my limited WCC experience, prayers (sung or spoken, the Lord's Prayer, Creed, etc.), congregational songs (psalms, hymns, and spiritual songs), symbols (water and fire), and certain postures and gestures (standing, sitting, kneeling, bowing, lifted hands, etc.) are commonplace. These can readily be woven together to create a meaningful ecumenical experience. Equally important is to remember that not all worship elements of one's denomination are readily understood or accepted by others-for example, the celebration of the Eucharist or the use of inclusive language for God. Being hospitable and willing to consider alternatives may help the process of reconciliation and building credible unity. Instead of celebrating the Eucharist, consider implementing the Moravian love feast in its place.

Finally, ensure the service design strengthens congregational participation by providing a variety of "toe-holds." Common solutions such as familiar congregational songs and prayers can be included. Other possibilities include instituting a brief time of rehearsal for the attending congregants a few minutes before the service, selecting proficient song leaders, musicians, and engaging worship leaders who can competently lead the gathering. It is important to remember that a well-designed ordo is only as good as its rendering in performance practice. To that end, providing sufficient time for rehearsal for all involved is paramount so that the worship of God can be meaningfully experienced.

\section{In Closing}

Ecumenical worship services have the tendency to take worshippers out of their comfort zones. For some, it is akin to the potting experience in the gardening world where such transplanting into new soil and larger pots usher in flourishing growth-if the work is done with much care. In this article, I sought to describe and showcase the AWPC of the WCC as it designed the various prayers for the 11th assembly to be held in Karlsruhe, Germany. The objective of this participant-observer approach was to offer best-practice principles in ecumenical worship in multi-ethnic and multicultural settings as gleaned from the working of the AWPC.

In this examination, I highlighted various points from an important document of the WCC. Created in 2002 following the 8th assembly of the WCC in Harare, this Final Report of the Special Commission on Orthodox Participation in the WCC provided guidelines for planning ecumenical worship. In this document, the WCC introduces the concept of 


\begin{abstract}
"Interconfessional common prayer" that it practices and explains why it discourages using the nomenclature ecumenical worship. This change is grounded in the distinctive context that the "prayer is rooted in the past experience of the ecumenical community as well as in the gifts of the member churches to each other. But it does not claim to be the worship of any given member church, or of any kind of a hybrid church or super-church" (World Council of Churches, Central Committee 2002, Final Report, article 42). Indeed, the ordo does not belong to any confession (or denomination), yet its use presents an opportunity for heartfelt mutual sharing of liturgical treasures and expressions as championed by Spiritual and Receptive Ecumenism in its journey towards overt Christian unity instead of being a "leastcommon-denominator" worship form. Aligned with that purpose, this article showcased a method in planning ecumenical worship and identified elements that this worship genre needs to consider in its rendition. It provided theological guidance for decision making in the worship design. Closing out this article, I offered three best-practice principles to strengthen ecumenical worship practice by local congregations keen to experience the tangible expression of reconciliation and be the visible sign of Christian unity.
\end{abstract}

Funding: This research received no external funding.

Institutional Review Board Statement: Not applicable.

Informed Consent Statement: Not applicable.

Data Availability Statement: Not applicable.

Conflicts of Interest: The author declares no conflict of interest.

\title{
References
}

Berger, Teresa. 2003. Worship in the Ecumenical Movement. In Ecumenical Dictionary: Article of the Month Series. Geneva: World Council of Churches. Available online: http:/ / www.wcc-coe.org/wcc/who/dictionary-article3.html (accessed on 15 November 2021).

Grace, Eden. 2002. Worship in the Context of the WCC: The Tradition of "Ecumenical Worship" in Light of the Recent Orthodox Critique. The Ecumenical Review 54: 3-27. [CrossRef]

Hammes, Verena. 2021. "The Soul of an Assembly" The Theme of the 11th Assembly of the World Council of Churches in 2022 Seen through the Lens of Previous Assembly Themes. The Ecumenical Review 73: 404-16. [CrossRef]

Lumma, Liborius Olaf. 2018. Ecumenical Services-A Little Known Type. Pray Tell: Worship, Wit \& Wisdom. March 15. Available online: https:/ /www.praytellblog.com/index.php/2018/03/15/ecumenical-services-a-little-known-type/ (accessed on 15 November 2021).

Pacific Mountain Regional Council Archives, United Church of Canada. 1983. WCC Assembly Highlights \#1; Video, 29:38. Vancouver: Pressure Point-Interchurch Television. Available online: https:/ /youtu.be/4WjCEulYwMo (accessed on 15 November 2021).

Pizzey, Antonia. 2019. Receptive Ecumenism and the Renewal of the Ecumenical Movement: The Path of Ecclesial Conversion. Boston: Brill. [CrossRef]

Roman Catholic Church, Pontifical Council for Promoting Christian Unity. 1993. Ecumenical Directory: Directory for the Application of Principles and Norms on Eumenism. Available online: http://www.christianunity.va/content/unitacristiani/en/documenti/ testo-in-inglese.html (accessed on 15 November 2021).

World Council of Churches, Faith and Order Commission. 1952. Report of the Third World Conference on Faith and Order, Lund, Sweden: 15-28 August 1952. Available online: https:/ / archive.org/details/wccfops2.017 (accessed on 25 December 2021).

World Council of Churches. 1990. Let the Spirit Speak to the Churches: A Guide for the Study of the Theme and the Issues, World Council of Churches, Seventh Assembly 1991. Geneva: WCC Publications.

World Council of Churches, Central Committee. 2002. Final Report of the Special Commission on Orthodox Participation in the WCC. Geneva: World Council of Churches. Available online: https:/ / www.oikoumene.org/resources/documents/final-report-of-thespecial-commission-on-orthodox-participation-in-the-wcc (accessed on 15 November 2021).

World Council of Churches. 2013. Tenth Assembly of the World Council of Churches, 30 October-8 November. Available online: http:/ / wcc2013.info/en.html (accessed on 15 November 2021).

World Council of Churches. 2019. Prayer will be the Heartbeat of WCC 11th Assembly. WCC News. Web Article (17 July). Available online: https:/ / www.oikoumene.org/news/prayer-will-be-heartbeat-of-wcc-11th-assembly (accessed on 15 November 2021).

World Council of Churches. 2021. Sharing and Learning: Bible, Mission, and Receptive Ecumenism. Geneva: World Council of Churches. Available online: https://www.oikoumene.org/sites/default/files/2021-12/SharingAndLearning_Web.pdf (accessed on 15 December 2021). 